\title{
Point of tangency between coronavirus disease and endothelial injury
}

\author{
So Sampei ${ }^{1,2}$, Hideshi Okada ${ }^{*}$ (D), Hiroyuki Tomita ${ }^{3}$, Akio Suzuki ${ }^{4}$, Takahide Nawa ${ }^{2}$ and Shinji Ogura ${ }^{1}$
}

Keywords: COVID-19, SARS-CoV-2, RT-PCR, Glycocalyx

To the Editor,

We report on a 74-year-old patient with severe pneumonia who had negative results on the first two reverse transcription-polymerase chain reaction (RT-PCR) examinations (at hospital days 1 and 4). His medical history and computed tomography findings strongly suggested coronavirus disease-2019 (COVID-19) (Fig. 1). Moreover, he had been undergoing hemodialysis for 5 years for chronic renal failure due to diabetic nephropathy. The patient tested positive on the third RT-PCR examination and was diagnosed as having a COVID-19 infection on hospital day 7.

RT-PCR, which targets selected genes of the severe acute respiratory syndrome-coronavirus-2 (SARS$\mathrm{CoV}-2) \mathrm{RNA}$, has been the primary diagnostic tool for COVID-19. However, several reports have criticized this method, particularly its sensitivity [1], as false-positive or false-negative results are commonly observed and are caused by factors such as sampling errors, RT-PCR inaccuracy, and low amount of viral particles. In addition, it was recently reported that for patients with type 2 diabetes PCR testing needs to be repeated to diagnose COVID-19 [1].

It is thought that the primary target of SARS-CoV2 is lung epithelial cells. Conversely, previous postmortem analysis showed viral elements within endothelial cells and accumulation of inflammatory cells, with evidence of endothelial and inflammatory cell death [2]. It is probable that endotheliitis occurs subsequent to systemic inflammation and thrombosis caused by initial lung epithelial cell infection in COVID-19, despite non-direct viral infection of the endothelial cells; however, the underlying mechanisms remain incompletely understood.

SARS-CoV-2 infection has been associated with endothelial glycocalyx injury [3]. The endothelial glycocalyx coats the healthy vascular endothelium and is essential in microvascular and endothelial physiology as it regulates leukocyte adhesion and migration while inhibiting intravascular thrombosis. In a healthy person, the receptors related to adhesion on the endothelium surface are covered by glycocalyx. However, when the endothelial glycocalyx is reduced, these receptors are exposed on the surface of the endothelium. The reduced thickness of the endothelial glycocalyx is more pronounced in patients with diabetes mellitus, cardiovascular disease, hyperlipidemia, and hypertension as well as in the elderly and in smokers. These are also the underlying diseases that can increase the severity of COVID-19 [3]. Furthermore, the endothelial glycocalyx is reportedly injured in patients with COVID-19 [4].

A previous study suggested that the endothelial glycocalyx was already injured in diabetic patients and that widespread inflammatory cell migration aggravated inflammation [5]. Thus, the inflammation can become severe even with a low viral load. A similar phenomenon may occur in patients with an

* Correspondence: hideshi@gifu-u.ac.jp

1 Department of Emergency and Disaster Medicine, Gifu University Graduate

School of Medicine, 1-1 Yanagido, Gifu 501-1194, Japan

Full list of author information is available at the end of the article 

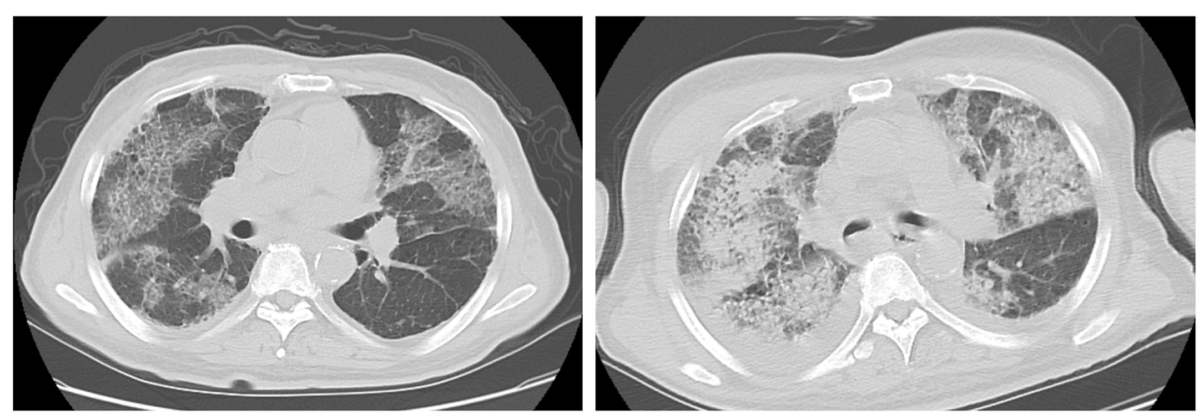

Fig. 1 Lung computed tomography at hospital days 1 (Left Panel) and 4 (right panel). Although these findings strongly suggested COVID-19, both of RT-PCR examinations resulted negative

endothelial glycocalyx injured by an underlying disease not limited to diabetes. However, this is circumstantial and indirect evidence.

The direct relationship between COVID-19 and endothelial glycocalyx injury requires further investigation. Future studies are needed to establish the diagnostic and therapeutic importance of the endothelial glycocalyx.

\section{Abbreviations}

COVID-19: Coronavirus disease-2019; RT-PCR: Reverse transcriptionpolymerase chain reaction; SARS-CoV-2: Severe acute respiratory syndromecoronavirus-2

\section{Acknowledgements}

The authors would like to thank the paramedical crew for sharing and allowing us to use the data they obtained for this case report. We would like to thank Editage (www.editage.com) for the English language editing.

\section{Authors' contributions}

SS and TN treated the patient. HO wrote the manuscript. HT and AS revised the manuscript. SO supervised this study. The authors read and approved the final manuscript.

\section{Funding}

Not applicable

\section{Availability of data and materials}

The datasets used and/or analyzed during the current study are available from the corresponding author on reasonable request.

\section{Declarations}

\section{Ethics approval and consent to participate}

In Japan, approval from an ethics committee is not required for case reports. This study was reported in accordance with the Ethical Guidelines for Medical and Health Research Involving Human Subjects established by the government of Japan.

\section{Consent for publication}

Written informed consent was obtained from the patient's legal guardians for the publication of this case report and any accompanying images. A copy of the consent form is available for the Editor-in-Chief of the International Journal of Emergency Medicine to review.

\section{Competing interests}

The authors declare that they have no competing interests.

\section{Author details}

'Department of Emergency and Disaster Medicine, Gifu University Graduate School of Medicine, 1-1 Yanagido, Gifu 501-1194, Japan. ${ }^{2}$ Department of Internal Medicine, Seiryu Hospital, Gifu, Japan. ${ }^{3}$ Department of Tumor
Pathology, Gifu University Graduate School of Medicine, Gifu, Japan. ${ }^{4}$ Department of Pharmacy, Gifu University Hospital, Gifu, Japan.

Received: 9 October 2021 Accepted: 12 December 2021

Published online: 20 December 2021

\section{References}

1. Salerno S, Zhao Z, Prabhu Sanakar S, Salvatore M, Gu T, Fritsche LG, et al. Patterns of repeated diagnostic testing for COVID-19 in relation to patient characteristics and outcomes. J Intern Med. 2021;289(5):726-37. https://doi. org/10.1111/joim.13213.

2. Varga Z, Flammer AJ, Steiger $P$, Haberecker $M$, Andermatt $R$, Zinkernagel AS, et al. Endothelial cell infection and endotheliitis in COVID-19. Lancet. 2020; 395(10234):1417-8. https://doi.org/10.1016/50140-6736(20)30937-5.

3. Okada H, Yoshida S, Hara A, Ogura S, Tomita H. Vascular endothelial injury exacerbates coronavirus disease 2019: the role of endothelial glycocalyx protection. Microcirculation. 2021;28(3):e12654. https://doi.org/10.1111/ micc.12654

4. Suzuki K, Okada H, Tomita H, Sumi K, Kakino Y, Yasuda R, et al. Possible involvement of Syndecan-1 in the state of COVID-19 related to endothelial injury. Thromb J. 2021;19(1):5. https://doi.org/10.1186/s12959-021-00258-x.

5. Sampei S, Okada H, Tomita H, Takada C, Suzuki K, Kinoshita T, et al. Endothelial glycocalyx disorders may be associated with extended inflammation during endotoxemia in a diabetic mouse model. Front Cell Dev Biol. 2021;9:623582. https://doi.org/10.3389/fcell.2021.623582.

\section{Publisher's Note}

Springer Nature remains neutral with regard to jurisdictional claims in published maps and institutional affiliations.

\section{Ready to submit your research? Choose BMC and benefit from:}

- fast, convenient online submission

- thorough peer review by experienced researchers in your field

- rapid publication on acceptance

- support for research data, including large and complex data types

- gold Open Access which fosters wider collaboration and increased citations

- maximum visibility for your research: over $100 \mathrm{M}$ website views per year

At $\mathrm{BMC}$, research is always in progress.

Learn more biomedcentral.com/submission 